CATHERINE DAVIS is a lecturer in communication studies at UNITEC, Auckland.

\title{
Delving into the complexity of NZ
}

documentary

Observations: Studies in New Zealand documentary, by Russell Campbell. Wellington: Victoria University Press, 2011, 260 pp. ISBN 978-0864736567

$\mathrm{R}$ USSELL CAMPBELL, author of Observations: Studies in New Zealand Documentary has been described as a 'partisan reporter', the book as a 'series of dispatches from the front'. Aligning the author on a series of borders between intellectual and practical, the book has been divided into three appropriate sections; Workers and Stirrers, State of the Nation and Kiwi Culture that support the author's commitment to the latter. Woven in, topics such as industrial unrest, feminist movements and Māori resurgence capture a sense of the contested versions of New Zealand depicted in these documentaries.

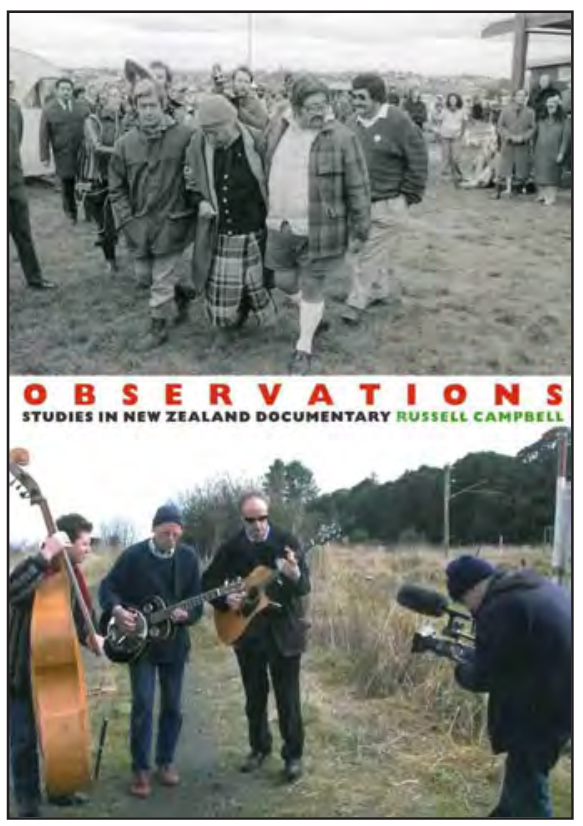

The war metaphor illustrates Campbell's critical position, asserting that documentary has a significant part to play in forging a sense of contested national identity. For Campbell, the goal of this book is to consider ways the 'New Zealand Documentary film has traced [a] process, as it has contributed to the debates about national identity in the social, political, and economic fields' (p. 223).

At times there is an inherent expectation that there is increased validity of the work due to the fact that the writer/academic is a practitioner. However, this can be justified by the historical lack of consideration of the production aspect of documentary 
making in much academic writing on documentary and suggests a closer relationship between media practitioners and academics in tertiary institutions across New Zealand.

Campbell is an exemplary example of a documentary practitioner who has forged the time and place as adjunct professor of film at Victoria University of Wellington, to make this fusion explicit.

It should be noted that documentary making is hard graft and some of the independent productions included may be called 'labours of love', so much so that it is unlikely that a practitioner would have time to develop this type of commentary. What is more often the case is a warehouse full of production notes, letters, storyboards, research; an archive of historical process that remains hidden behind the final visual production.

Campbell has been granted access to some of these archives and shared some of the relationships, tensions and practical work of a range of documentary. Still, it is likely that there is more to be uncovered about this type of construction of New Zealand and one would hope this book is the beginning of other work of this type.

By admission, the productions selected do, as Campbell asserts, 'display a preoccupation with notions of national identity...' (p. 217), and the range of documentaries further '...provide comparison between the status quo and others that are the ground of open disputes about what sort of society we are or want to be' (p. 217). This range from status quo to dispute, results in a considerable attempt to be inclusive throughout the book as the chapters cover diverse documentary discourse from union struggles to the relationship between poetry represented in documentary.

Although the chapters themselves may be described as an attempt to reconsider the ideological notions that abound with the idea of national identity, many of the documentaries may still be described as highbrow, reinforcing the notion of documentary as an elite form belonging in the traditional Sunday slot.

The documentaries considered are certainly not the fodder of mainstream television, although there are some exceptions such as New Zealand Wars (1998) that pushed the boundaries of historical representation on prime time television. Consequently, the range of the book does not look closely at institutional motivations of Television New Zealand or its planning for documentary funding in New Zealand, although Campbell looks to a future television culture that may support the range of documentaries covered in the book. 
Although this book is a culmination of disparate essays written over a period of 25 years and covering the years 1940 to 2010, Campbell moves smoothly between the challenging style of mixing theoretical and practical considerations of documentary making as including appropriate historical, cultural and economic material. What emerges are in-depth analysis of various documentary discourse supported by explicitly made links between local practice and theory.

The book includes independently made work and non-prime time television series that lie on the margins but are remembered by an author with an astute knowledge of industry, well supported by in-depth textual analysis. For those interested in documentary in general and the fashioning of New Zealand on screen, this book is a rare event in New Zealand publishing history as such focused work of this kind are uncommon.

One is reminded of Annie Goldson's Landscape, Memory, Dad and Me (2006) publication on the documentary Wake and Barry Barclay's Our own image (2009) that stand among several other significant works delving deeper into the complexity of New Zealand documentary.

\section{References}

Barclay, B. (1990) Our own image. Auckland, N.Z: Longman Paul.

Belich, J., Stephens, T., and McRae, C. (1998). The New Zealand wars. Auckland: Television New Zealand Ltd., Landmark Productions.

Campbell, R. (2011). Observations: Studies in New Zealand documentary. Wellington: Victoria University Press. Goldson, A. (2006) Landscape, memory, dad and me. Wellington: Victoria University Publications. 